This is the accepted version of the article:

Aríñez-Soriano J ., Albalad J., Pérez-Carvajal J., I maz I., Busqué F., Juanhuix J., Maspoch D.. Two-step synthesis of heterometallic coordination polymers using a polyazamacrocyclic linker. CrystEngComm, (2016). 18. : 4196 - . 10.1039/c5ce02520f.

Available at: https://dx.doi.org/10.1039/c5ce02520f 


\section{Two-step synthesis of heterometallic coordination polymers using a polyazamacrocyclic linker +}

Received 00th January 20xx, Accepted 00th January 20xx

DOI: $10.1039 / x 0 \times x 00000 x$

\author{
J. Aríñez-Soriano, ${ }^{a}$ J. Albalad, ${ }^{a}$ J. Pérez-Carvajal, ${ }^{a}$ I. Imaz ${ }^{{ }^{*}}$, F. Busqué ${ }^{b}$, J. Juanhuix ${ }^{c}$ and D. \\ Maspoch $^{\text {ad* }}$
}

A new macrocyclic linker 1,4,7,10-tetraazacyclododecane-1,7-bis(4-acetamidobenzoic)-4,10-diacetic acid $\mathrm{H}_{4} \mathrm{~L} \mathbf{1}$ was synthesized and characterized. This linker was used to create two heterometallic coordination polymers following a twostep synthesis. This synthesis consisted on first combining this polyazamacrocyclic linker with $\mathrm{Ni}$ (II) or $\mathrm{Mn}$ (II) ions to obtain the corresponding metallomacrocyclic complexes showing non-coordinated carboxylic groups. In a second step, these metallated macrocycles were used as building units to construct two heterometallic $\mathrm{Ni}(\mathrm{II})-\mathrm{Zn}$ (II) and $\mathrm{Mn}$ (II)- $\mathrm{Zn}$ (II) coordination polymers when combined with Zn(II) ions. In addition, a third Zn(II)-Zn(II) coordination polymer could also be synthesized by direct mixing of $\mathrm{H}_{4} \mathrm{L1}$ with $\mathrm{Zn}$ (II) ions. Interestingly, the $\mathrm{Mn}(\mathrm{II})-\mathrm{Zn}$ (II) coordination polymer exhibits a reversible Type-I "crystal-to-amorphous transformation" upon water sorption/desorption.
Polyazamacrocycles (cyclen and cyclam derivatives) are a family of heteromolecules with high affinity to chelate metal ions in their cavities thanks to the preorganization of their binding sites and their kinetic and thermodynamic stability induced by the macrocyclic effect. ${ }^{9,10}$ Because of this affinity, these macrocyclic ligands have already shown promise in different fields ranging from contrast agents ${ }^{11}$ and catalysis ${ }^{12,13}$ to sensors. ${ }^{14}$ Recently, the functionalization of the reactive amine positions of polyazamacrocycles with pendant arms incorporating functional groups (e.g. carboxylates, amides, and phosphonates) ${ }^{15-18}$ has opened the possibility to use them as multitopic organic linkers. These organic linkers have the potential to coordinate a metal ion inside the inner cavity and different ones through these pendant arms, extending the framework and thus forming heterometallic coordination polymers. However, their use as linkers for the synthesis of coordination polymers is up to date limited; only a few examples of homometallic, ${ }^{19-26}$ and even less of heterometallic ${ }^{27}$ coordination polymers are found in the literature. This scarcity of structures can be attributed to their high degree of flexibility that difficult obtaining suitable crystals for single-crystal X-ray diffraction, to their sensitivity to harsh reaction media, and to the tendency of their pendant arms to coordinate the metal ions within the macrocyclic cavity, ${ }^{28}$ thereby promoting the generation of mononuclear compounds rather than coordination polymers.

Herein, we present the stepwise synthesis of heterometallic coordination polymers using polyazamacrocycles as organic linkers. Our strategy consists on first preparing complexes of the polyazamacrocycle 1,4,7,10-tetraazacyclododecane-1,7-bis(4acetamidobenzoic)-4,10-diacetic acid ( $\left.\mathrm{H}_{4} \mathrm{~L} \mathbf{1}\right)$ with $\mathrm{Mn}(\mathrm{II})$ and $\mathrm{Ni}(\mathrm{II})$ ions, and then using these metallated macrocycles as secondary building units to create heterometallic coordination polymers. We show that the coordination of these $\mathrm{Mn}(\mathrm{II}) / \mathrm{Ni}(\mathrm{II})$ building units

sensors, pollutant removal, and antibacterials. 
showing free carboxylic groups with $\mathrm{Zn}(\mathrm{II})$ ions allows the synthesis of two bimetallic $\mathrm{Zn}$ (II)-Mn(II) and $\mathrm{Zn}$ (II)-Ni(II) coordination polymers (Scheme 1). We also show that a $\mathrm{Zn}(\mathrm{II})-\mathrm{Zn}$ (II) coordination polymer could be synthesized by direct mixing of $\mathrm{H}_{4} \mathrm{~L} \mathbf{1}$ with $\mathrm{Zn}$ (II) ions. Interestingly, the $\mathrm{Mn}$ (II)-Zn(II) coordination polymer shows a reversible Type-I "crystal-to-amorphous transformation" upon water sorption/desorption. ${ }^{29}$

\section{Experimental}

\section{General Considerations}

Tert-butyl 4-aminobenzoate, bromoacetyl bromide, potassium carbonate and trifluoroacetic acid were purchased from SigmaAldrich. DO2AtBu (a.k.a. di-tert-butyl 2,2'-(1,4,7,10tetraazacyclododecane-1,7-diyl)diacetate) was purchased from CheMatech. All solvents were purchased from Fisher Scientific and Scharlab. Solvents and reagents were used as received unless otherwise stated. ${ }^{1} \mathrm{H}$ and ${ }^{13} \mathrm{C}$ NMR spectra of intermediates $\mathbf{1}$ and $\mathbf{2}$ were recorded on a Bruker Avance DPX-360 spectrometer operating at 360 and $90 \mathrm{MHz}$, respectively. ${ }^{1 \mathrm{H}}$ and ${ }^{13} \mathrm{C}$ NMR spectra of $\mathbf{H}_{\mathbf{4}} \mathbf{L} \mathbf{1}$ were recorded on a Bruker Avance III 400 SB operating at 400 and $100 \mathrm{MHz}$ respectively. Samples were dissolved in $\mathrm{CDCl}_{3}$ or $\mathrm{D}_{2} \mathrm{O}$ after purification. Mass spectra were acquired on a micrOTOF-QII ESI-MS instrument. Purity of all bulk material batches was confirmed by Xray powder diffraction (XRPD) patterns collected on an X'Pert PRO MPD analytical diffractometer (Panalytical) at $45 \mathrm{kV}, 40$ $\mathrm{mA}$ using $\mathrm{Cu} \mathrm{K} \alpha$ radiation ( $\lambda 1.5419 \AA$ ) , and compared with single crystal simulated patterns. Thermogravimetric analyses were performed under nitrogen flow using a STA 449 F1 JupiterSimultaneous TGA-DSC from NETZSCH with a heat rate of $5^{\circ} \mathrm{C} / \mathrm{min}$.
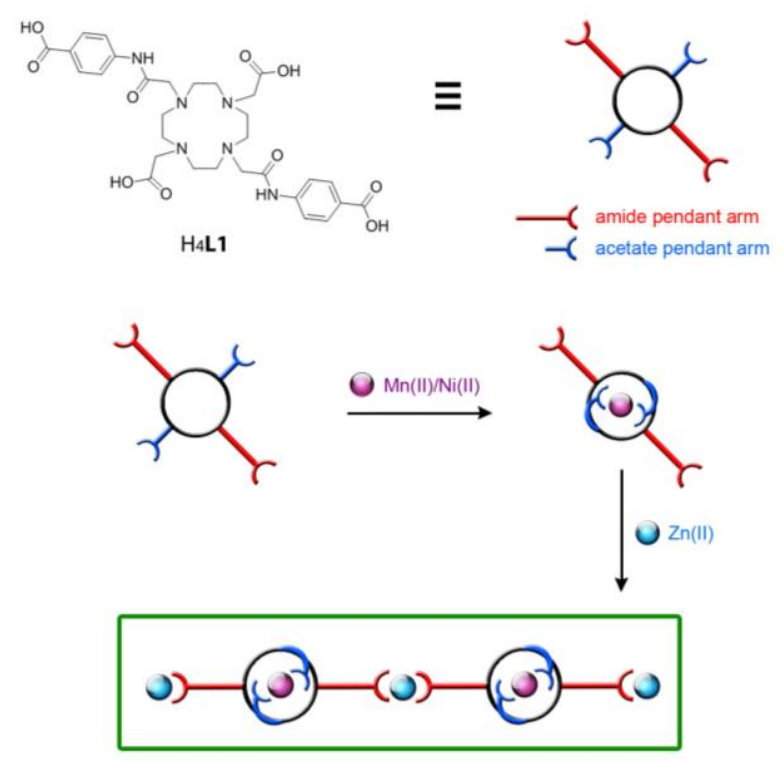

Scheme 1. Illustration showing the two-step strategy followed to synthesize the heterometallic coordination polymers 6 and 7 .

IR spectra were recorded in transmission mode on a Bruker Tensor 27FTIR equipped with a Golden Gate diamond ATR cell. Gravimetric water sorption measurements were performed at $298 \mathrm{~K}$ using a flow of nitrogen, up to relative humidity of $90 \%$ with a DVSAdvantage-1 (Surface Measurements Systems). Elemental Analysis measurements were performed on a Flash EA 2000 CHNS, Thermo Fisher Scientific analyser.

\section{Synthesis of the linker}


Synthesis of 4-tert-butyl(2-bromoacetamido)benzoate (1). 1 was synthesized adapting a literature procedure. ${ }^{15}$ To a solution of tertbutyl 4-aminobenzoate $(5.0 \mathrm{~g}, 26.2 \mathrm{mmol})$ in dichloromethane (100 $\mathrm{mL})$ was added potassium carbonate $(4.0 \mathrm{~g}, 28.8 \mathrm{mmol})$. The reaction mixture was stirred vigorously and cooled to $0{ }^{\circ} \mathrm{C}$ in an ice bath. Bromoacetyl bromide $(2.5 \mathrm{~mL}, 28.8 \mathrm{mmol})$ was added dropwise afterwards. The reaction mixture was allowed to warm to room temperature, and then stirred for $12 \mathrm{~h}$. The resulting mixture was then filtered over Celite ${ }^{\circledR}$, the solids were discarded and the filtrate was concentrated by evaporation of the solvents under vacuum. Yield: $6.64 \mathrm{~g}$ (21.2 mmol, 65\%). Found: C $49.8 \%, \mathrm{H} 4.9 \%, \mathrm{~N}$ $4.7 \%$; $\mathrm{C}_{13} \mathrm{H}_{16} \mathrm{NO}_{3} \mathrm{Br}$ requires: C $49.7 \%$, $\mathrm{H} 5.1 \%$, N $4.5 \%$. ${ }^{1} \mathrm{H}$ NMR $\left(360 \mathrm{MHz}, \mathrm{CDCl}_{3}\right): \delta=8.26(1 \mathrm{H}, \mathrm{s} \mathrm{br}, \mathrm{NH}), 8.02\left(2 \mathrm{H}, \mathrm{d},{ }^{3} \mathrm{~J}_{\mathrm{H}-\mathrm{H}}=7.5 \mathrm{~Hz}\right.$, $\operatorname{Ar}), 7.63\left(2 \mathrm{H}, \mathrm{d}, 3^{3} \mathrm{H}_{-\mathrm{H}}=7.5 \mathrm{~Hz}, \mathrm{Ar}\right), 4.07\left(2 \mathrm{H}, \mathrm{s}, \mathrm{BrCH}_{2}\right), 1.61(9 \mathrm{H}, \mathrm{s}$, $\left.\mathrm{C}\left(\mathrm{CH}_{3}\right)_{3}\right) .{ }^{13} \mathrm{C} \mathrm{NMR}\left(90 \mathrm{MHz}, \mathrm{CDCl}_{3}\right): \delta=164.8(\mathrm{C}=\mathrm{O}), 163.09(\mathrm{C}=\mathrm{O})$,

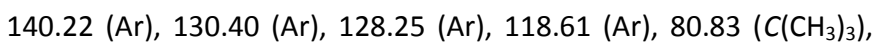

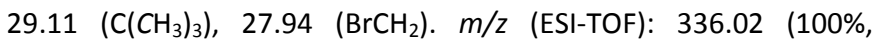
$\left.[\mathrm{M}+\mathrm{Na}]^{+}\right)$, an appropriate isotope pattern was observed.

Synthesis of 1,4,7,10-tetraazacyclododecane-1,7-bis(4-tertbutylacetamidobenzoate)-4,10-bis(tert-butylacetate) (2). To a solution of bromoacetamide $1(1.78 \mathrm{~g}, 5.70 \mathrm{mmol})$ in acetonitrile (50 mL) was added DO2AtBu (1.09 g, $2.71 \mathrm{mmol}$ ) and potassium carbonate $(0.94 \mathrm{~g}, 6.78 \mathrm{mmol})$. The reaction mixture was heated under reflux at $85{ }^{\circ} \mathrm{C}$ for $72 \mathrm{~h}$. The resulting mixture was then filtered over Celite ${ }^{\circ}$ to remove the inorganic salts, and the filtrate was concentrated by evaporation of the solvents under vacuum. Finally, the title compound was purified by column chromatography over silica gel, eluting with $13 \%$ methanol in dichloromethane, to obtain an analytical sample. Yield: $1.41 \mathrm{~g}(1.63 \mathrm{mmol}, 60 \%)$. Found: C $59.2 \%, \mathrm{H} 7.7 \%$, N $9.1 \% ; \mathrm{C}_{46} \mathrm{H}_{70} \mathrm{~N}_{6} \mathrm{O}_{10} \mathrm{Br}$ requires: $\mathrm{C} 58.3 \%, \mathrm{H} 7.6$ \%, N $8.9 \% .{ }^{1} \mathrm{H}$ NMR $\left(360 \mathrm{MHz}, \mathrm{CDCl}_{3}\right): \delta=7.96\left(4 \mathrm{H}, \mathrm{d},{ }^{3} \mathrm{~J}_{\mathrm{H}-\mathrm{H}}=7.5 \mathrm{~Hz}\right.$, $\operatorname{Ar}), 7.65\left(2 \mathrm{H}, \mathrm{d}, 3_{\mathrm{H}-\mathrm{H}}=7.5 \mathrm{~Hz}, \mathrm{Ar}\right), 3.30\left(4 \mathrm{H}, \mathrm{s},-\mathrm{NCH}_{2} \mathrm{CONH}-\right), 3.11$ $\left(4 \mathrm{H}, \mathrm{s},-\mathrm{NCH}_{2} \mathrm{COO}-\right), 2.96\left(8 \mathrm{H}, \mathrm{s},-\mathrm{NCH}_{2} \mathrm{CH}_{2} \mathrm{~N}-\right), 2.80(8 \mathrm{H}, \mathrm{s},-$ $\left.\mathrm{NCH}_{2} \mathrm{CH}_{2} \mathrm{~N}-\right), 1.57\left(18 \mathrm{H}, \mathrm{s}, \mathrm{C}\left(\mathrm{CH}_{3}\right)_{3}\right), 1.38\left(18 \mathrm{H}, \mathrm{s}, \mathrm{C}\left(\mathrm{CH}_{3}\right)_{3} .{ }^{13} \mathrm{C} \mathrm{NMR}\right.$ (90 MHz, $\left.\mathrm{CDCl}_{3}\right): \delta=170.4\left(\mathrm{CH}_{2} \mathrm{COO}^{t} \mathrm{Bu}\right), 169.5\left(\mathrm{CH}_{2} \mathrm{CONH}\right), 165.2$
$51.8\left(\mathrm{NCH}_{2} \mathrm{CH}_{2} \mathrm{~N}\right), 48.1\left(\mathrm{NCH}_{2} \mathrm{CH}_{2} \mathrm{~N}\right), 28.0\left(\mathrm{C}\left(\mathrm{CH}_{3}\right)_{3}\right), 27.8\left(\mathrm{C}\left(\mathrm{CH}_{3}\right)_{3}\right)$. $\mathrm{m} / \mathrm{z}$ (ESI-TOF): $889.50\left(100 \%,[\mathrm{M}+\mathrm{Na}]^{+}\right)$, an appropriate isotope pattern was observed.

Synthesis of 1,4,7,10-tetraazacyclododecane-1,7-bis(4acetamidobenzoic)-4,10-diacetic acid $\left(\mathrm{H}_{4} \mathbf{L} \mathbf{1}\right)$. To a solution of $\mathbf{2}$ $(0.96 \mathrm{mmol})$ in dichloromethane $(15 \mathrm{~mL})$ was added trifluoroacetic acid $(15 \mathrm{~mL})$. The reaction mixture was stirred at room temperature for $16 \mathrm{~h}$ to promote the cleavage of the tert-butyl groups. The resulting mixture was evaporated under vacuum at low temperature $\left(30^{\circ} \mathrm{C}\right)$ until dryness. The residue was taken up in methanol and the solvent was evaporated again. Finally, the residue was dissolved in the minimum amount of methanol and precipitated by addition of diethyl ether to properly recover a pale white solid. To further purify the compound, $\mathbf{H}_{4} \mathbf{L} \mathbf{1}(1 \mathrm{~g})$ was dissolved in deionized water $(100 \mathrm{~mL})$ and the $\mathrm{pH}$ was set to 2.5 by adding concentrated hydrochloric acid to recrystallize the compound. Yield: $1.23 \mathrm{~g}$ (2.0 mmol, $91 \%$ ). Found: C $44.4 \%, \mathrm{H} 7.0 \%$, $\mathrm{N} 10.3 \% ; \mathrm{C}_{30} \mathrm{H}_{38} \mathrm{~N}_{6} \mathrm{O}_{10} \cdot 8 \mathrm{H}_{2} \mathrm{O}$ requires: $\mathrm{C} 45.7 \%, \mathrm{H} 7.2 \%, \mathrm{~N} 10.6 \%$. ${ }^{1} \mathrm{H}$ NMR $\left(400 \mathrm{MHz}, \mathrm{CDCl}_{3}\right): \delta=7.72\left(4 \mathrm{H}, \mathrm{d},{ }^{3} \jmath_{\mathrm{H}-\mathrm{H}}=7.5 \mathrm{~Hz}, \mathrm{Ar}\right), 7.37$ $\left(4 \mathrm{H}, \mathrm{d}, 3 \mathrm{~J}_{\mathrm{H}-\mathrm{H}}=7.5 \mathrm{~Hz}, \mathrm{Ar}\right), 3.24\left(4 \mathrm{H}, \mathrm{s}, \mathrm{NCH}_{2} \mathrm{COO}\right), 2.88(4 \mathrm{H}, \mathrm{s}$, $\left.\mathrm{NCH}_{2} \mathrm{CONH}\right), 2.43\left(16 \mathrm{H}\right.$, mult., $\left.\mathrm{NCH}_{2} \mathrm{CH}_{2} \mathrm{~N}\right) .{ }^{13} \mathrm{C} \mathrm{NMR}(100 \mathrm{MHz}$, $\left.\mathrm{CDCl}_{3}\right): \delta=179.9\left(\mathrm{CH}_{2} \mathrm{COO}\right), 174.9\left(\mathrm{CH}_{2} \mathrm{CONH}\right), 172.3(\mathrm{ArCOO}), 140.6$ (NH-Ar) 132.0 (Ar), 129.8 (Ar-COO), 120.6 (Ar), 58.7 ( $\left.\mathrm{NCH}_{2} \mathrm{CONH}\right)$, $57.8\left(\mathrm{NCH}_{2} \mathrm{COO}\right), 50.5\left(\mathrm{NCH}_{2} \mathrm{CH}_{2} \mathrm{~N}\right) . \mathrm{m} / z$ (ESI-TOF): 665.25 (100\%, $\left.\left[\mathrm{H}_{4} \mathrm{~L} 1+\mathrm{Na}\right]^{+}\right)$, an appropriate isotope pattern was observed. $\mathrm{v}_{\max }$ (FTIR, cm ${ }^{-1}$ ): 3222m, 2995w, 2366s, 2341s, 1686s, 1598s, 1535s, 1409s, 1258s, 1170s, 1094s.

\section{Synthesis of discrete complexes}

Synthesis of $\left[\mathrm{Mn}\left(\mathrm{H}_{1} \mathrm{~L} 1\right)\right] \cdot\left[\mathrm{Na}\left(\mathrm{H}_{2} \mathrm{O}\right)_{6}\right] \cdot 4 \mathrm{H}_{2} \mathrm{O}(3)$. A stirred mixture of $\mathrm{H}_{4} \mathrm{~L} \mathbf{1}(1.0 \mathrm{~g}, 1.56 \mathrm{mmol})$ in water $(100 \mathrm{~mL})$ was basified to $\mathrm{pH}=$ 8.0 with $1 \mathrm{M}$ sodium hydroxide. Then, manganese chloride (195.8 $\mathrm{mg}, 1.56 \mathrm{mmol})$ in water $(2 \mathrm{~mL})$ was added dropwise into the<smiles>Nc1ccc(C(=O)OCCCCCCC(=O)CBr)cc1</smiles><smiles>O=C(CBr)Nc1ccc(C(=O)O[Ga]C(=O)CBr)cc1</smiles>

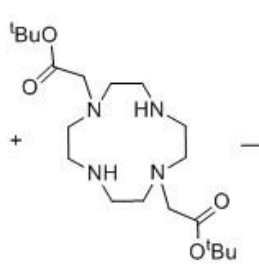

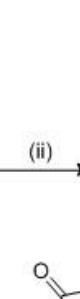

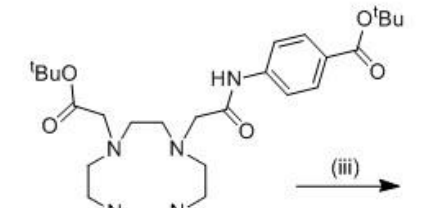<smiles>C=CC(=C)NC(=O)CN1CCN(CC(=O)O)CCN(CC(=O)Nc2ccc(C(=O)O)cc2)CCN(CC(=O)O)CC1</smiles>

Scheme 2. Synthetic route for the synthesis of $\mathrm{H}_{4} \mathrm{LI}$. Reagents and conditions: (i) $\mathrm{K}_{2} \mathrm{CO}_{3}, \mathrm{CH}_{2} \mathrm{Cl}_{2}, 0^{\circ} \mathrm{C}$ to RT $12 \mathrm{~h}$; (ii) $\mathrm{K}_{2} \mathrm{CO}_{3}, \mathrm{CH}_{3} \mathrm{CN}$, reflux $85^{\circ} \mathrm{C} 72 \mathrm{~h}+$ column chromatography $13 \% \mathrm{MeOH}$ in $\mathrm{CH}_{2} \mathrm{Cl}_{2}$; (iii) Trifluoroacetic acid, $\mathrm{CH}_{2} \mathrm{Cl}_{2}, 16 \mathrm{~h}$.

(ArCOO $\left.{ }^{t} \mathrm{Bu}\right), 141.5$ (NH-Ar) 130.6 (Ar), 126.9 (Ar-COO), $117.4(\mathrm{Ar})$, $81.0\left(C\left(\mathrm{CH}_{3}\right)_{3}\right), 80.6\left(C\left(\mathrm{CH}_{3}\right)_{3}\right), 56.8\left(\mathrm{NCH}_{2} \mathrm{CONH}\right), 52.4\left(\mathrm{NCH}_{2} \mathrm{COO}\right)$, 
Table 1. Crystallographic data of $\mathrm{H}_{4} \mathbf{L} \mathbf{1}$, discrete complexes $\mathbf{3}$ and $\mathbf{4}$; and coordination polymers $\mathbf{5 , 6}$ and $\mathbf{7}$.

\begin{tabular}{|c|c|c|c|c|c|c|}
\hline Compound reference & H4L1 & 3 & 4 & 5 & 6 & 7 \\
\hline Chemical Formula & $\mathrm{C} 30 \mathrm{H} 38 \mathrm{~N} 6 \mathrm{O} 10,7 \mathrm{H} 2 \mathrm{O}$ & $\begin{array}{c}\text { C30 H35 Mn N6 O10, } \\
\text { Na(H2O)6, 5H2O }\end{array}$ & $\mathrm{C} 30 \mathrm{H} 36 \mathrm{~N} 6 \mathrm{NiO} 10, \mathrm{H} 2 \mathrm{O}$ & $\begin{array}{c}\text { C30H34N6O11Zn2, } \\
\text { 3H2O }\end{array}$ & $\begin{array}{c}\mathrm{C} 30 \mathrm{H} 34 \mathrm{~N} 6 \mathrm{NiO} 11 \mathrm{Zn}, \\
8 \mathrm{H} 2 \mathrm{O}\end{array}$ & $\begin{array}{c}\mathrm{C} 30 \mathrm{H} 34 \mathrm{~N} 6 \mathrm{MnO} 11 \mathrm{Zn}, \\
9 \mathrm{H} 2 \mathrm{O}\end{array}$ \\
\hline Formula Mass & 768.66 & 915.3 & 717.36 & 845.37 & 861.37 & 918.94 \\
\hline Crystal System & Monoclinic & Monoclinic & Monoclinic & Monoclinic & Monoclinic & Monoclinic \\
\hline $\mathrm{a} / \AA$ & $13.691(4)$ & $11.730(4)$ & $18.780(4)$ & $10.830(3)$ & $11.360(3)$ & $37.000(4)$ \\
\hline $\mathrm{b} / \AA$ & $22.544(4)$ & $19.810(4)$ & $18.110(4)$ & $18.480(3)$ & $22.080(3)$ & $12.500(4)$ \\
\hline c/ $\AA$ & $11.572(4)$ & $17.130(4)$ & $9.200(4)$ & $16.550(3)$ & $15.560(3)$ & $18.680(4)$ \\
\hline$\alpha$ & 90 & 90 & 90 & 90 & 90 & 90 \\
\hline$\beta$ & $96.98(4)$ & $105.77(4)$ & $106.22(4)$ & $103.90(4)$ & $90.20(3)$ & $111.40(3)$ \\
\hline$\gamma$ & 90 & 90 & 90 & 90 & 90 & 90 \\
\hline Unit Cell Volume & 3545.2 & $3830.7(17)$ & $3004.4(17)$ & $3215.3(13)$ & 3902.(14) & $8044(4)$ \\
\hline Temperature & 150 & 150 & 150 & 150 & 150 & 150 \\
\hline Space Group & $\mathrm{C} 2 / \mathrm{c}$ & $\mathrm{P} 21 / \mathrm{c}$ & $\mathrm{C} 2 / \mathrm{c}$ & $\mathrm{P} 21 / \mathrm{n}$ & $\mathrm{P} 21 / \mathrm{n}$ & $\mathrm{C} 2 / \mathrm{c}$ \\
\hline $\mathrm{Z}$ & 4 & 4 & 4 & 4 & 4 & 8 \\
\hline Reflections Measured & 23208 & 17623 & 5619 & 8378 & 111901 & 29802 \\
\hline Independent Reflections & 3632 & 8623 & 2984 & 3420 & 5038 & 4738 \\
\hline Reflections $(I>2 \sigma(I))$ & 2885 & 7786 & 2077 & 1497 & 4415 & 3765 \\
\hline Rint & 0.0402 & 0.0267 & 0.042 & 0.117 & 0.099 & 0.057 \\
\hline $\mathrm{R} 1(\mathrm{I}>2 \sigma(\mathrm{I}))$ & 0.1019 & 0.1088 & 0.0841 & 0.0951 & 0.1057 & 0.1041 \\
\hline$w R(F 2)(I>2 \sigma(I))$ & 0.2711 & 0.3021 & 0.2394 & 0.2204 & 0.3426 & 0.1171 \\
\hline$R_{1}$ (all data) & 0.1222 & 0.1144 & 0.1095 & 0.1989 & 0.1127 & 0.3237 \\
\hline$w R\left(F^{2}\right)$ (all data) & 0.2549 & 0.3088 & 0.2671 & 0.2896 & 0.3522 & 0.3450 \\
\hline
\end{tabular}


previous solution. After this, the $\mathrm{pH}$ of the stirred mixture was readjusted again to 8.0 , and the mixture was left at room temperature under stirring for $18 \mathrm{~h}$. The $\mathrm{pH}$ of the suspension was again adjusted to $\mathrm{pH}=12$ to precipitate the excess of manganese chloride in the form of insoluble manganese hydroxides. The mixture was filtered and the solids discarded. The filtrate was then acidified to $\mathrm{pH}=3$ with $1 \mathrm{M}$ hydrochloric acid to precipitate $\mathbf{3}$. The precipitated complex was centrifuged, the solvent was exchanged by fresh deionized water, and the solid was resuspended. This process was repeated twice. Finally, the suspension was filtered and the pale yellow solid was air-dried. Yield: $1.1 \mathrm{~g}$ (1.36 mmol, 87\%). Found: $\mathrm{C}, 45.4 \%, \mathrm{H} 5.7 \%, \mathrm{~N} 10.4 \% ; \mathrm{C}_{30} \mathrm{H}_{47} \mathrm{~N}_{6} \mathrm{O}_{16} \mathrm{MnNa}$ requires: $\mathrm{C}$ 43.6 \%, H 5.7 \%, N 10.2 \%. m/z (ESl-): 694.18 ([Mn(HL1)]', 100\%), an appropriate isotope pattern was observed. $v_{\max }\left(A T R, \mathrm{~cm}^{-1}\right): 3222 \mathrm{~m}$, $2968 w, 2366 s, 2341$ s, 1686s, 1598s, 1535s, 1409s, 1258s, 1170s, $1094 \mathrm{~s}$.

Synthesis of $\left[\mathrm{Ni}\left(\mathrm{H}_{2} \mathrm{~L} 1\right)\right] \cdot 2 \mathrm{H}_{2} \mathrm{O}(4) .4$ was prepared following the same procedure as for $\mathbf{3}$, except that nickel acetate $(388 \mathrm{mg}, 1.56$ $\mathrm{mmol}$ ) was used as the metal ion precursor, obtaining 4 as a light pink powder. Yield: $352 \mathrm{mg}(0.50 \mathrm{mmol}, 35 \%)$. Found: C $48.0 \%, \mathrm{H}$ $5.3 \%, \mathrm{~N} 11.1 \% ; \mathrm{C}_{30} \mathrm{H}_{37} \mathrm{~N}_{6} \mathrm{O}_{10} \mathrm{Ni} \cdot 2 \mathrm{H}_{2} \mathrm{O}$ requires: $\mathrm{C} 49.0 \%, \mathrm{H} 5.5 \%, \mathrm{~N}$ $11.4 \% . \mathrm{m} / \mathrm{z}\left(\mathrm{ESI}^{+}\right): 699.19\left(\left[\mathrm{Ni}\left(\mathrm{H}_{3} \mathrm{~L} 1\right)\right]^{+}, 100 \%\right)$, an appropriate isotope pattern was observed. $v_{\max }\left(\mathrm{FTIR}, \mathrm{cm}^{-1}\right): 3222 \mathrm{~m}, 2995 \mathrm{w}$, 2366s, 2341s, 1686s, 1598s, 1535s, 1409s, 1258s, 1170s, 1094 s.

\section{Synthesis of coordination polymers}

Synthesis of $\left[\mathrm{Zn}(\mathrm{ZnL1}) \mathrm{H}_{2} \mathrm{O}\right] \cdot 3 \mathrm{H}_{2} \mathrm{O}$ (5). A solution of zinc acetate $(85.6 \mathrm{mg}, 390 \mu \mathrm{mol})$ in distilled water $(2 \mathrm{~mL}$ ) was added dropwise to a solution of $\mathbf{H}_{4} \mathbf{L} \mathbf{1}(100 \mathrm{mg}, 156 \mu \mathrm{mol})$ in $10 \mathrm{~mL}$ of pure water, adjusted to $\mathrm{pH}=6.7$. After 10 minutes, the solution became cloudy leading to the precipitation of a white crystalline powder of $\mathbf{5}$. The powder was then collected by centrifugation, washed several times in pure water and maintained on the same solvent. Yield: $47 \mathrm{mg}(68$ $\mu \mathrm{mol}, 47 \%)$. Found: C $42.5 \%, \quad \mathrm{H} \quad 5.1 \%$, N $10.1 \%$; $\mathrm{C}_{30} \mathrm{H}_{36} \mathrm{~N}_{6} \mathrm{O}_{11} \mathrm{Zn}_{2} \cdot 3 \mathrm{H}_{2} \mathrm{O}$ requires: C $42.8 \%$, H $5.0 \%, \mathrm{~N} 10.0 \%$. $v_{\max }$ (FTIR, cm ${ }^{-1}$ ): 3453w, 2927m, 2871m, 1673s, 1595vs, 1550s, 1472w, $1416 \mathrm{~m}, 1371 \mathrm{~m}, 1304 \mathrm{~s}, 1259 \mathrm{~s}, 1203 \mathrm{~m}, 1158 \mathrm{~s}, 1091 \mathrm{~s}, 923 \mathrm{~s}$. Experimental vs simulated PXRD pattern can be found in ESIt.

Synthesis of [ $\left.\mathrm{Zn}(\mathrm{NiL1}) \mathrm{H}_{2} \mathrm{O}\right] \cdot 8 \mathrm{H}_{2} \mathrm{O}$ (6). A mixture of 4 (133 mg, $154 \mathrm{mmol}$ ) and zinc acetate $(67.6 \mathrm{mg}, 308 \mathrm{mmol})$ in pure distilled water was basified to $\mathrm{pH}=6.5$ with $1 \mathrm{M} \mathrm{NaOH}$. The solution was allowed to react for $12 \mathrm{~h}$ at $85{ }^{\circ} \mathrm{C}$. After this period, plate-shaped crystals of $\mathbf{4}$ were collected by filtration, washed several times in pure water, and air-dried. Yield: $52.0 \mathrm{mg}(74 \mu \mathrm{mol}, 52 \%)$. Found: $\mathrm{C}$ $39.1 \%, \mathrm{H} 5.8 \%$, N $8.8 \%$; $\mathrm{C}_{30} \mathrm{H}_{36} \mathrm{~N}_{6} \mathrm{O}_{11} \mathrm{NiZn} \cdot 8 \mathrm{H}_{2} \mathrm{O}$ requires: $\mathrm{C} 39.0 \%$, H $5.7 \%$, N $9.0 \%$. $v_{\max }\left(\mathrm{FTIR}, \mathrm{cm}^{-1}\right): 3342 \mathrm{~m}, 2860 \mathrm{w}, 1600 \mathrm{~s}, 1529 \mathrm{~m}$, $1372 \mathrm{~s}, 1305 \mathrm{~m}, 1260 \mathrm{~m}, 1182 \mathrm{~m}, 1092 \mathrm{~m}, 924 \mathrm{~m}$. Experimental vs simulated PXRD pattern can be found in ESIt.

Synthesis of $\left[\mathrm{Zn}(\mathrm{MnL1}) \mathrm{H}_{2} \mathrm{O}\right] \cdot 9 \mathrm{H}_{\mathbf{2}} \mathrm{O}$ (7). A solution of zinc acetate $(75 \mathrm{mg}, 340 \mu \mathrm{mol})$ in distilled water $(10 \mathrm{~mL})$ was added dropwise to a solution of $3(10 \mathrm{~mL}, 136 \mu \mathrm{mol})$ in water at room temperature and $\mathrm{pH}=8.5$. After $10 \mathrm{~min}$., white crystals of $\mathbf{7}$ were collected by filtration, washed several times in pure water, and air-dried. Yield: $68.6 \mathrm{mg}(97 \mu \mathrm{mol}, 68 \%)$. Found: C $37.5 \%$, H $5.6 \%$, N $8.6 \%$;
$\mathrm{C}_{30} \mathrm{H}_{36} \mathrm{~N}_{6} \mathrm{O}_{11} \mathrm{MnZn} \cdot 9 \mathrm{H}_{2} \mathrm{O}$ requires: $\mathrm{C} 38.4 \%, \mathrm{H} 5.8 \%, \mathrm{~N} 8.9 \%$. $v_{\max }$ (FTIR, cm ${ }^{-1}$ ): 3275m, 2972w, 2872w, 1663w, 1585s, 1540s, 1372s, $1316 \mathrm{~s}, 1260 \mathrm{~s}, 1170 \mathrm{~m}, 1092 \mathrm{~s}, 1003 \mathrm{w}, 969 \mathrm{~m}$. Experimental vs simulated PXRD pattern can be found in ESIt.

\section{X-Ray Crystallography}

Refinement and structural information is shown in Table 1. Crystallographic data for 3-5 were collected at $293 \mathrm{~K}$ at 119 beamline at Diamond synchrotron $(\lambda=0.6889 \AA)$. These data were indexed, integrated and scaled using CrystalClear software from Rigaku group programs. Absorption correction was performed by Multi-Scan method giving max./min. transmission factors of $1.000 / 0.923$ (3), $1.000 / 0.654$ (4), and $1.000 / 0.448$ (5). Crystallographic data for 6 and 7 were collected at $100 \mathrm{~K}$ at XALOC beamline at ALBA synchrotron ( $\lambda=0.71049 \AA$ ). These data were indexed, integrated and scaled using the XDS and IMOSFLM programs. ${ }^{30}$ Absorption correction was not applied. Crystallographic data for $\mathrm{H}_{4} \mathrm{~L} \mathbf{1}$ was collected at $293 \mathrm{~K}$ on a Bruker AXS SMART Apex diffractometer using graphite monochromated Mo-K $\alpha$ radiation $(\lambda=$ $0.71073 \AA)$, and it was corrected for Lorentz and polarisation effects. The frames were integrated with the Bruker SAINT software package. Absorption corrections were applied using SADABS giving max./min. transmission factors of $1.000 / 0.270$. The structures were solved by direct methods and subsequently refined by correction of F2 against all reflections using SHELXS2013 and SHELXL2013 within the WinGX package. ${ }^{31}$ All non-hydrogen atoms were refined with anisotropic thermal parameters by full-matrix least-squares calculations on F2 using SHELXL2013. Hydrogen atoms were inserted at calculated positions and constrained with isotropic thermal parameters. The hydrogen of the different hydratation water molecules present in all six structures were not located on Fourier map, but were added in the empirical formula to allow accurate determination of density and absorption coefficient. The structure of 3 contains disordered $\left[\mathrm{Na}\left(\mathrm{H}_{2} \mathrm{O}\right)_{6}\right]^{+}$. Two sites were identified corresponding to disordered partial-occupancy sodium atoms (one in special position) and were refined with occupancy factors of $0.75 / 0.25$. Due to this disorder, the oxygen atoms coordinated to these sodium ions were located and refined with different occupancy factors to correlate the different occupancies to the presence of this $\left[\mathrm{Na}\left(\mathrm{H}_{2} \mathrm{O}\right)_{6}\right]^{+}$. CCDC $1443836-1443841$.

\section{Results and discussion}

\section{Crystal structures of $\mathrm{H}_{4} \mathrm{~L} 1$ and complexes 3 and 4}

$\mathbf{H}_{4} \mathbf{L} \mathbf{1} \cdot \mathbf{8} \mathrm{H}_{2} \mathrm{O}$. Suitable crystals of $\mathrm{H}_{4} \mathrm{L1}$ for single-crystal $\mathrm{X}$-ray diffraction were obtained by diffusion of acidic vapours into a solution of $\mathrm{H}_{4} \mathbf{L} \mathbf{1}(5 \mathrm{mg} / \mathrm{mL})$ in water placed in the fridge at $5{ }^{\circ} \mathrm{C}$ for one week. The structure was solved and refined in the monoclinic space group $\mathrm{C2} / \mathrm{c}$. The asymmetric unit was found to contain one half of the macrocyclic $\mathrm{H}_{4} \mathrm{~L} \mathbf{1}$ together with four water molecules; being the remaining macrocyclic atomic positions generated by a twofold rotation axis piercing through the central cavity (Figure 1a). Charge balance considerations and the location of residual Fourier peaks suggest that $\mathrm{H}_{4} \mathrm{~L} \mathbf{L}$ is protonated on two of the four central nitrogen atoms (N2 and N2\#) and on two of the four carboxylic 
moieties (O2 and O2\#). The macrocycles $\mathrm{H}_{4} \mathbf{L} \mathbf{1}$ are linked by hydrogen-bonded interactions between them and water molecules to form 1D chains extending along the ac plane (Figure S9, ESIt). Water molecules act as connectors between two $\mathrm{NH}$ of the amide

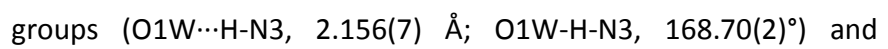
between two deprotonated $\mathrm{C}-\mathrm{O}$ of the acetate pendant arms

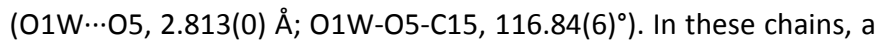
deprotonated $\mathrm{C}-\mathrm{O}$ of the acetate pendant arms is also forming hydrogen bonds with a benzene carboxylic acid group $(\mathrm{O}-\mathrm{H})$ of the

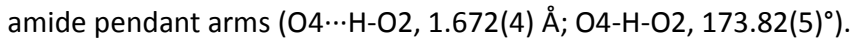

$\left[\mathrm{Mn}\left(\mathrm{H}_{1} \mathrm{~L} \mathbf{1}\right)\right] \cdot\left[\mathrm{Na}\left(\mathrm{H}_{2} \mathrm{O}\right)_{6}\right] \cdot \mathbf{4} \mathrm{H}_{2} \mathrm{O}$ (3). Suitable crystals for single-crystal $\mathrm{X}$-ray diffraction were obtained by slow diffusion of acid vapours into a basic solution of 3 in water $(5 \mathrm{mg} / \mathrm{mL}, \mathrm{pH}=8.5)$ at $5{ }^{\circ} \mathrm{C}$ for one week. Analysis of these crystals by single crystal $\mathrm{X}$-ray diffraction gave a structure model in the monoclinic space group $P 2_{1} / c$, where the asymmetric unit was found to contain one L1 macrocycle coordinated to a single $\mathrm{Mn}$ (II) ion (Figure $1 \mathrm{~b}$ ) and one disordered $\left[\mathrm{Na}\left(\mathrm{H}_{2} \mathrm{O}\right)_{6}\right]^{+}$counterion. The $\mathrm{Mn}(\mathrm{II})$ ion is placed within the macrocyclic cavity in a square antiprismatic molecular geometry. The square antiprism has one plane defined by the four aza nitrogen atoms from the macrocyclic core, and the other plane defined by $\mathrm{O} 1$ and $\mathrm{O} 6$ of the amide groups and $\mathrm{O} 4$ and 09 of the acetate pendant arms. $\mathrm{Mn}(\mathrm{II})$ ion lies 1.324(0) $\AA$ above the plane formed by the four aza nitrogen atoms and 1.219(3) $\AA$ below the plane defined by the four oxygen atoms. The presence of a $\mathrm{Na}$ cation means that $\mathbf{3}$ must negatively charged. By comparing the $\mathrm{C}-\mathrm{O}$ distances of both benzene carboxylic acid groups, it can be noted that C28-O7 distance $(1.319(7) \AA$ ) is longer compared to C28-O8

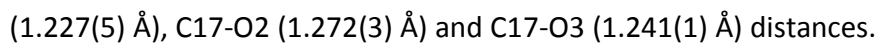
These differences indicate that 07 is protonated while the others are not. In the structure, this benzene carboxylic acid group is participating in a hydrogen bond with an acetate pendant arm

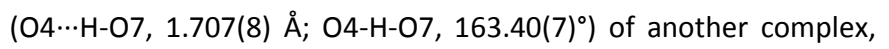
while the amide group of the same amide pendant arm is $\mathrm{H}$-bonded with the benzene carboxylic acid group of the non-equivalent amide

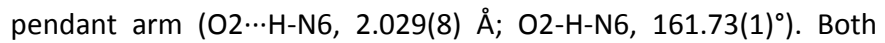
types of hydrogen bonds define the formation of an $\mathrm{H}$-bonded layer (Figure $\mathrm{S} 10, \mathrm{ESI}^{+}$). In these layers, two equivalent protonated benzenecarboxylic aromatic rings also form an offset face-to-face $\pi-\pi$ interaction with a distance of $3.701(6) \AA$ from centroid to centroid.

$\left[\mathbf{N i}\left(\mathrm{H}_{2} \mathrm{~L} \mathbf{1}\right)\right] \cdot \mathbf{2} \mathrm{H}_{2} \mathrm{O}$ (4). Crystals of 4 suitable for single-crystal X-ray diffraction were obtained by slow diffusion of acid vapours into a basic solution of 4 in water $(5 \mathrm{mg} / \mathrm{mL}, \mathrm{pH}=8.5)$ at $5{ }^{\circ} \mathrm{C}$ for one week. The structure was solved and refined in the monoclinic space group $C 2 / c$, where the asymmetric unit was found to contain one half of the complex. L1 coordinates to a single $\mathrm{Ni}(\mathrm{II})$ ion within the macrocyclic cavity in a highly distorted octahedral geometry (Fig. 1c). In this case, the four nitrogen atoms are far from being coplanar, laying at $0.397(4) \AA$ from the average plane. The coordination sphere of $\mathrm{Ni}(\mathrm{II})$ is formed by the four aza nitrogen atoms and two equivalent $\mathrm{O} 4$ atoms of the acetate pendant arms. Contrary to 3 , the oxygen atoms of the amide groups are not a)

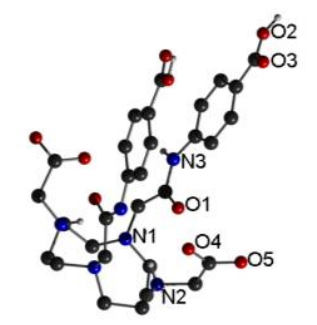

b)

c)
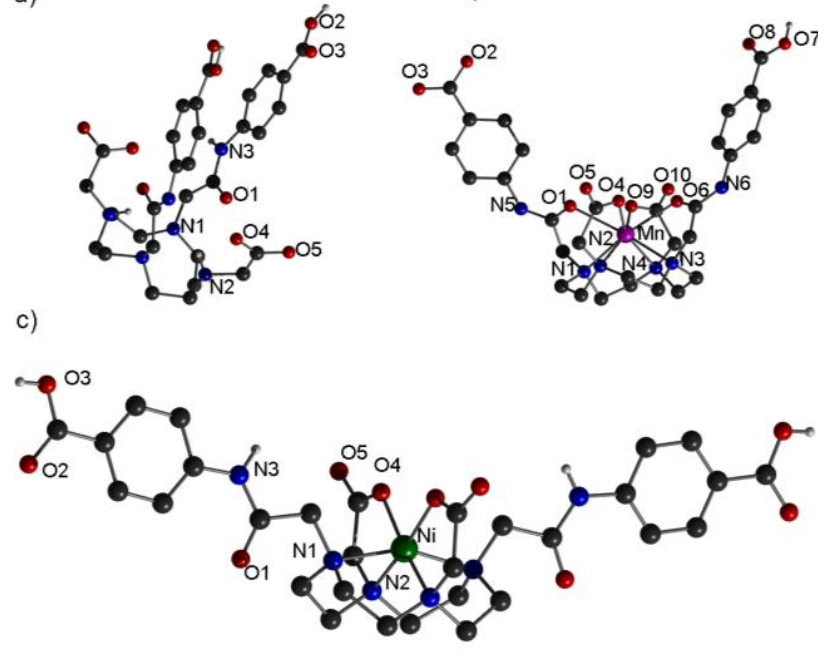

Fig. 1. Ball and stick representation of the crystal structures of (a) $\mathrm{H}_{4} \mathbf{L} \mathbf{1}$, (b) $\mathbf{3}$ and (c) 4. Structures are represented with unique heteroatom labelling. Hydrogen atoms describing the protonation state have been included, and the rest have been omitted for clarity.

involved on any coordination bond, leaving both pendant arms free to rotate. The absence of any counterion and the symmetry equivalence between the two amide pendant arms indicate that both benzene carboxylic acid groups are protonated. These complexes are linked by hydrogen bonds to form layers along the ac plane (Figure S11, ESIt). These layers are created by the typical $\mathrm{R}_{2}{ }_{2}(8) \quad \mathrm{H}$-bonded dimers formed through the two benzene

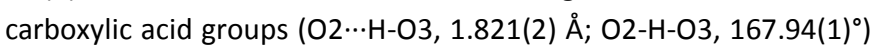
and hydrogen bonds involving $\mathrm{N}-\mathrm{H}$ of the amide groups and $\mathrm{C}=\mathrm{O}$ of

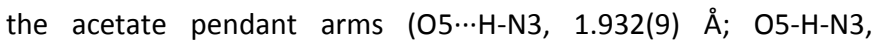
$\left.176.14(3)^{\circ}\right)$. These interactions formed a very compact structure in which only a hydrogen-bonded water molecule (O1W...04, 3.022(1) $\AA$; O O1W-O4-C15, 132.22(2) ${ }^{\circ}$ ) fits in the asymmetric unit.

\section{Crystal structures of coordination polymers}

$\left[\mathrm{Zn}(\mathrm{ZnL} \mathbf{1}) \mathrm{H}_{2} \mathrm{O}\right] \cdot 3 \mathrm{H}_{2} \mathrm{O}(\mathbf{5}) .5$ crystallises in the monoclinic space group $\mathrm{P} 2_{1} / \mathrm{n}$ forming a one-dimensional coordination polymer. Its asymmetric unit contains two $\mathrm{Zn}(\mathrm{II})$ ions exhibiting two different coordination environments. $\mathrm{Zn} 1$ is chelated within the macrocyclic cavity through the four aza nitrogen atoms, two acetate ( $\mathrm{O} 4$ and 09) pendant arms and 01 of the amide pendant arm in a capped trigonal prism molecular geometry (Figure 2a). Zn2 adopts a distorted square pyramidal geometry coordinated to two benzene carboxylate groups in a bidentate (07 and 08 ) and monodentate (O2) fashion, one acetate group (05) that bridges $\mathrm{Zn} 1$ and $\mathrm{Zn} 2$, and one water molecule (Figure $2 \mathrm{~b}$ ). The structure of $\mathbf{5}$ is constructed by the connection of $\mathrm{Zn} 2$ ions through three different L1 linkers, forming a double-strand chain in a zigzag conformation that extends along the $b$ axis (Figures $2 c, d$ ). The double-strand chains are then connected to each other along the $a$ direction through hydrogen bonds (Figure $2 \mathrm{~d}$ and Fig S12, ESIt). These hydrogen 

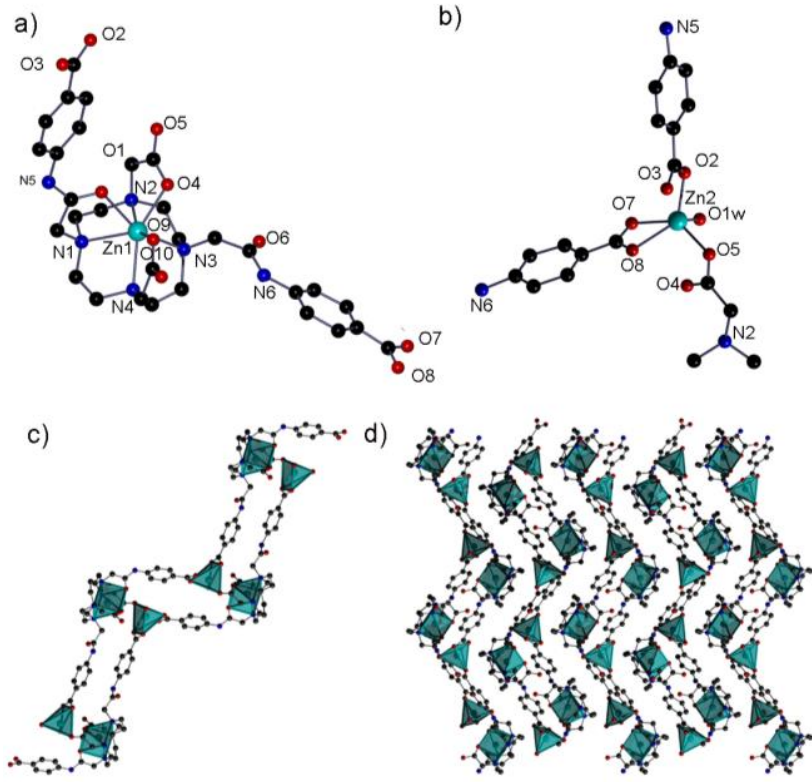

Fig. 2. Ball and stick representation of the crystal structure of 5. (a) Zn1-L1 unit. (b) Zn2 unit. (c) Double strand chain extending along the $b$ axis. (d) Packing of the double strand chains viewed along the $b$ axis. The sky blue capped trigonal prisms and square pyramids represent the coordination environment of $\mathrm{Zn}(\mathrm{II})$ in (c,d). $\mathrm{H}$ atoms have been omitted for clarity. Atom colour code: Zn: sky blue; C: black-grey; $\mathrm{N}$ : blue; O: red.

bonds are defined between the uncoordinated amide and the nonbridging acetate group $(\mathrm{O} 10 \cdots \mathrm{H}-\mathrm{N} 6,2.032(5) \AA \AA$; O10-H-N6, $\left.159.54(2)^{\circ}\right)$ and between a water molecule that acts as a connector between the coordinated amide group (O2W...H-N5, 1.913(2) $\AA$; O2W-H-N5, $\left.169.26(7)^{\circ}\right)$ and the bidentate benzene carboxylic acid group $\left(\mathrm{O} 2 \mathrm{~W} \cdots \mathrm{O} 8 \mathrm{8}, 2.852(1) \AA\right.$; O $\left.2 \mathrm{~W}-\mathrm{O} 8 \mathrm{-C} 28,149.13(5)^{\circ}\right)$.

[ $\left.\mathrm{Zn}(\mathrm{NiL1}) \mathrm{H}_{2} \mathrm{O}\right] \cdot 7 \mathrm{H}_{2} \mathrm{O}$ (6). 6 also crystallises in the monoclinic space group $\mathrm{P} 2_{1} / \mathrm{n}$, forming a one-dimensional coordination polymer. Its asymmetric unit contains a slightly modified building unit $\mathbf{4}$ (only the benzene rings are slightly rotated) and one $\mathrm{Zn}$ (II) ion connecting these units. As in 4, $\mathrm{Ni}(\mathrm{II})$ ion shows a distorted octahedral geometry coordinated by the four aza nitrogen atoms and $\mathrm{O} 4$ and 09 of two acetate pendant arms (Figure 3a). On the other hand, $\mathrm{Zn}(\mathrm{II})$ ion is tetrahedrally coordinated to two benzene carboxylate groups ( $\mathrm{O} 3$ and $\mathrm{O} 7$ ) acting both in a monodentate fashion, one $\mathrm{O5}$ of the acetate pendant arm and one water molecule (Figure $3 \mathrm{~b}$ ). In this structure, each Zn(II) ion connects three different nickelated L1 units creating a double strand chain extending along the [110] and [-110] directions (Figures 3c,d). The different chains form a crosslinked structure in which the water molecule $02 \mathrm{~W}$ acts as the connector between two different double-strand chains, forming hydrogen bonds with one of the amide groups (O2W-..H-N6, 2.023(3) $\AA$; O $\left.2 \mathrm{~W}-\mathrm{H} 6 \mathrm{~N}, 170.46(6)^{\circ}\right)$ and one oxygen atom from the

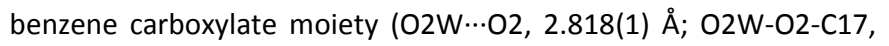
$\left.105.58(0)^{\circ}\right)$. Also, the coordinated water molecule forms a hydrogen

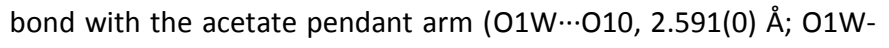
010-(30, 140.07(4) $)^{\circ}$.
$\left[\mathrm{Zn}(\mathrm{MnL1}) \mathrm{H}_{2} \mathrm{O}\right] \cdot 9 \mathrm{H}_{2} \mathrm{O}$ (7). $\mathbf{7}$ crystallises in the monoclinic space group $\mathrm{C} 2 \backslash \mathrm{C}$, forming a two-dimensional coordination polymer. The structural model shows a modified building unit $\mathbf{3}$ and one $\mathrm{Zn}$ (II) connecting these units. Indeed, if we compare the initial conformation of the building unit $\mathbf{3}$ with that found in 7, a clear difference is that the $\mathrm{Mn}(\mathrm{II})$ ion has changed its coordination number from eight to seven. This change leaves one amide pendant arm free to be accommodated in an extended position and thus, facilitates the coordination of $\mathrm{Zn}(\mathrm{II})$ ions with the two benzene carboxylic acid groups. In 7, the $\mathrm{Mn}$ (II) ion adopts a capped trigonal prismatic geometry coordinated to the four aza nitrogen atoms, 04 and 09 atoms of two acetate pendant arms and 01 of the amide pendant arm (Figure 4a). Similar to $6, \mathrm{Zn}$ (II) ion is tetrahedrally coordinated to two benzene carboxylate groups ( 02 and 07$)$ acting both in a monodentate fashion, one $\mathrm{O5}$ of the acetate pendant arm and one water molecule (Figure $4 \mathrm{~b}$ ). The coordination structure is built up from connecting each $\mathrm{Mn}$ (II)-L1 unit through three different $\mathrm{Zn2}$ ions (Figure 4c), forming corrugated layers that grow along the $(-101)$ plane. The different layers are packed in an $A B A B$ sequence connected via a water molecule, which directly connects these layers through two hydrogen bond interactions involving one amide pendant arm (O4W...H-N5, 2.130(5) $\AA$; O4W-H-N5, 157.09(0) ${ }^{\circ}$ ) and one benzene carboxylate moiety (O4W…02, 2.962(4) $\AA$; O4W-O2$\left.\mathrm{C} 17,132.79(2)^{\circ}\right)$, and weak contacts through their aliphatic moieties (Figures $4 \mathrm{~d}, \mathrm{e}$ and Figure $\mathrm{S} 14, \mathrm{ESI}^{+}$). As shown in Figure 4e, the remaining water molecules form independent $\mathrm{H}$-bonded networks

a)

b)

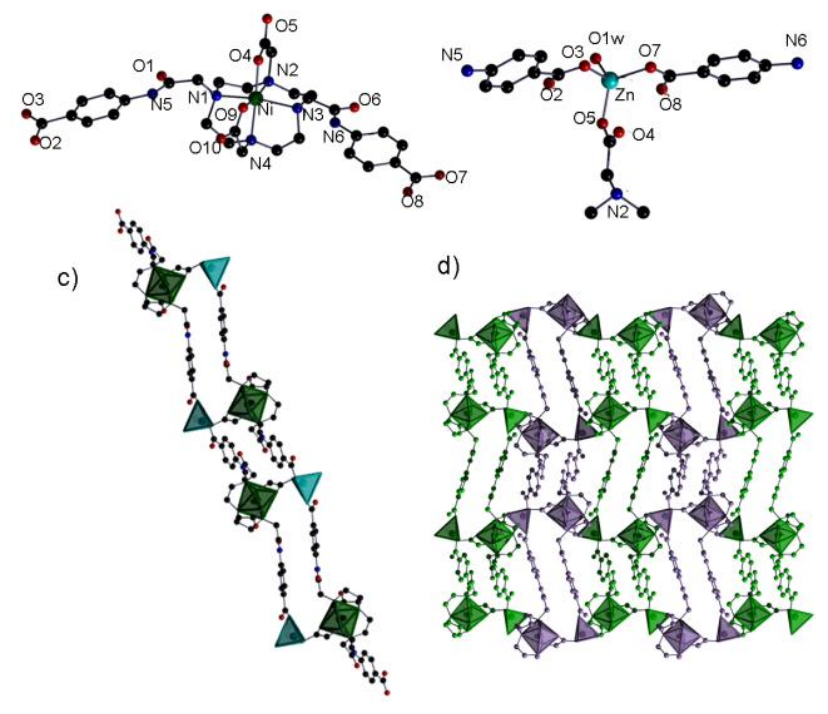

Fig. 3. Ball and stick representation of the crystal structure of 6. (a) Ni-L1 unit. (b) Zn unit. (c) Double strand chain extending along the [110] or [-110] direction. (d) Neighbouring double strand chains viewed along the $a$ axis. The green octahedra and sky blue tetrahedra represent the coordination environment of $\mathrm{Ni}(\mathrm{II})$ and $\mathrm{Zn}(\mathrm{II})$, respectively, in (c). Different chains have been differently coloured in (d). $\mathrm{H}$ atoms have been omitted for clarity. Atom colour code: Zn: sky blue; Ni: green; C: black-grey; N: blue; O: red. 
a)

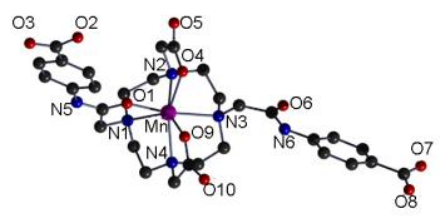

b)

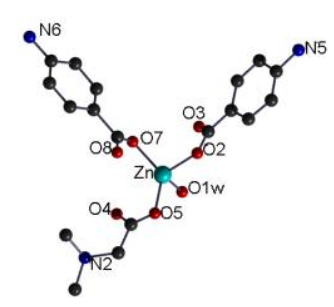

c)

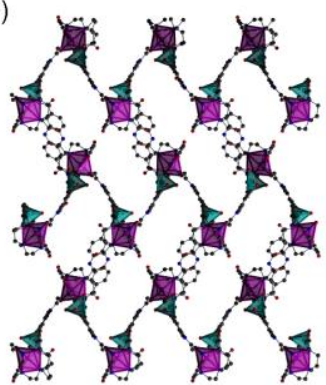

d)

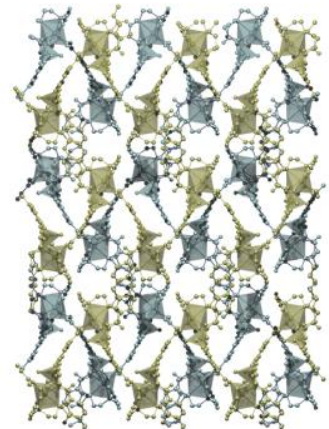

e)

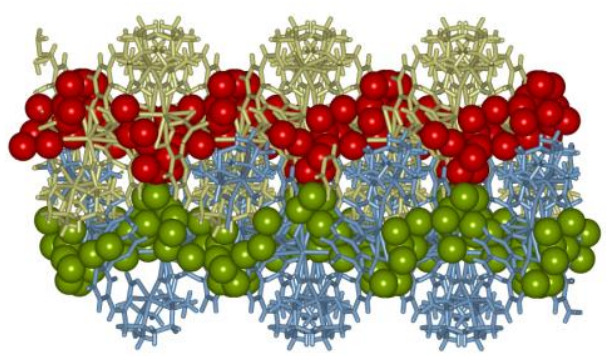

Fig. 4. Ball and stick representation of the crystal structure of 7. (a) Mn-L1 unit. (b) Zn unit. (c) Single coordination layer viewed along $c$ axis. (d) Two neighbouring layers viewed along $c$ axis. (e) Two neighbouring corrugated layers viewed along the [101] axis, showing the independent $\mathrm{H}$-bonded network of guest water molecules. The violet capped trigonal prisms and the sky blue tetrahedra represent the coordination environment of $\mathrm{Mn}(\mathrm{II})$ and $\mathrm{Zn}$ (II) in (c). The two layers in (d,e) and the two $\mathrm{H}$-bonded networks of water molecules in (e) have been differently coloured. $\mathrm{H}$ atoms have been omitted for clarity. Atom colour code: $\mathrm{Zn}$ : sky blue; Mn: violet; C: black-grey; N: blue; O: red

that run parallel to the plane $(-101)$.

\section{Structural integrity and water adsorption of 7.}

The high content of water molecules in the framework of 7 prompted us to investigate its behaviour upon water sorption /desorption. Initially, we performed a thermogravimetric analysis (TGA) on 7, showing a first weight loss of $21.2 \%$ from 20 to $120{ }^{\circ} \mathrm{C}$. This loss was attributed to the loss of all water molecules (19.2\%) according to the molecular formula $\left[\mathrm{Zn}(\mathrm{MnL} 1) \mathrm{H}_{2} \mathrm{O}\right] \cdot 9 \mathrm{H}_{2} \mathrm{O}$ (Figure $5 \mathrm{a})$. A second weight loss was found in the temperature range of $340-470^{\circ} \mathrm{C}$ corresponding to the decomposition of the framework.

To evaluate the water-vapour sorption properties, 7 was first activated at $120{ }^{\circ} \mathrm{C}$ overnight under vacuum, and the activated sample ( $7^{\prime}$ ) was characterized by TGA and PXRD (Figures 5a,b). TGA revealed the absence of any weight loss from 20 to $340{ }^{\circ} \mathrm{C}$, confirming that $\mathbf{7}$ ' was free of guest water molecules. On the other hand, the experimental PXRD showed that $7^{\prime}$ becomes an

amorphous material after evacuating the water molecules. This behaviour is not unexpected as layers of $\mathbf{7}$ are three-dimensionally packed via hydrogen-bonded water molecules, so that their removal is likely inducing their disordering and loss of crystallinity. Remarkably, the framework of $\mathbf{7}$ was recovered when 7' was reimmersed in water or exposed to water vapors (Figure 5b), as confirmed by X-ray powder diffraction (XRPD) patterns. This reversible behavior is typical of a Type-I "crystal-to-amorphous transformation" as described by Kitagawa et al. ${ }^{29}$

Dynamic water sorption measurements performed on $\mathbf{7}^{\prime}$ showed an adsorption branch with a sigmoidal shape representative of a type II trend. ${ }^{32}$ The water uptake reaches a plateau at a relative humidity $(\mathrm{RH})$ of $60 \%$, achieving an uptake of $0.23 \mathrm{~g} \mathrm{H}_{2} \mathrm{O} / \mathrm{g} \mathbf{7}^{\prime}$. The maximum water uptake was $0.26 \mathrm{~g} \mathrm{H}_{2} \mathrm{O} / \mathrm{g} \mathbf{7}^{\prime}$ at a $\mathrm{RH}$ of $90 \%$. This weight increase can be attributed to 10 water molecules (calculated on the basis of the dehydrated formula, theoretical $=24 \%$ ), in agreement with TGA results and the initial hydrated crystal structure. In addition, we observed hysteresis loop between the adsorption and desorption branches, from which a 5.1 $\%$ in weight was found that is not desorbed. This percentage can be attributed to two water molecules (calculated on the basis of the dehydrated formula, theoretical $=4.7 \%$ ) that cannot be desorbed without heating this material. We can tentatively ascribe these two water molecules to those that are more strongly bonded in the framework of 7; that is, $01 \mathrm{~W}$ that is coordinated to the $\mathrm{Zn}(\mathrm{II})$ ions (Figure $4 \mathrm{~b}$ ), and O4W that is the responsible of three-dimensionally connecting the coordination layers through several hydrogen bond interactions (Figure S14, ESI+). In fact, when performing an XRPD of the sample resulting from the desorption process, we could observe a certain degree of crystallinity, thus confirming that this sample shows a certain ordering between layers (Figure S15, ESI+).

We then performed six water sorption/desorption cycles by

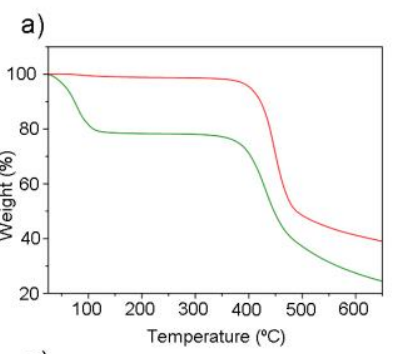

b)

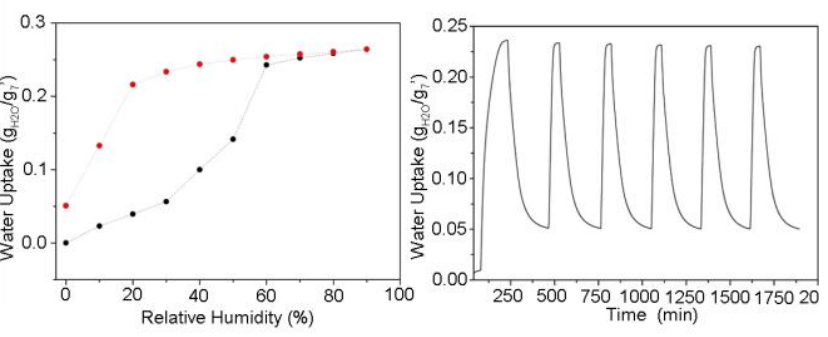

Fig. 5. (a) TGA of 7 (green) and 7' (red). (b) PXRD patterns of 7: simulated (black), as made (green), activated under vacuum at $120{ }^{\circ} \mathrm{C}$ (red), and activated and immersed in water for $48 \mathrm{~h}$ (blue). (c) Water isotherm of 7 at 25ㅇ. (d) Water sorption/desorption cycles at $60 \%$ and $2 \% \mathrm{RH}$. 
alternatively exposing the outgassed material to humid (60\% RH) and dry ( $2 \% \mathrm{RH})$ environments (Figure 5d). Remarkably, the maximum uptake at $60 \% \mathrm{RH}$ (ca. $23 \%$ ) was not significantly modified with the number of cycles, confirming the stability of the material to water sorption/desorption processes. Furthermore, it should be noted that the $5 \%$ in weight of water molecules that remains in the material after desorption reduces its working capacity. However, as counterpart, it makes the cycles narrower, meaning that this slightly crystalline material shows a faster response to water sorption than its amorphous analogue $\mathbf{7}^{\prime}$.

\section{Conclusions}

In conclusion, we have synthesised a tetraazacyclododecane-based linker $\mathrm{H}_{4} \mathbf{L} \mathbf{1}$, and demonstrated its versatility in the formation of two discrete $\mathrm{Mn}(\mathrm{II})$ and $\mathrm{Ni}(\mathrm{II})$ chelates showing free carboxylic groups. These complexes were further used, in a second step, as metallated building units to create two heterometallic $\mathrm{Zn}(\mathrm{II})-\mathrm{Ni}(\mathrm{II})$ (6) and $\mathrm{Zn}$ (II)-Mn(II) (7) coordination polymers. In addition, a third homometallic $\mathrm{Zn}(\mathrm{II})$-based coordination polymer (5) was synthesized by direct mixing $\mathrm{H}_{4} \mathrm{~L} \mathbf{1}$ with $\mathrm{Zn}(\mathrm{II})$ ions. 5 and 6 show extended double strand chains stacked to each other through hydrogen bonds, whereas $\mathbf{7}$ forms corrugated layers packed in an $A B A B$ fashion also containing independent $\mathrm{H}$-bonded networks of water molecules. Interestingly, this coordination polymer exhibits a reversible Type-I "crystal-to-amorphous transformation" upon water sorption/desorption, a plateau uptake of $23 \%$ in weight at 60 $\% \mathrm{RH}$, and is stable to at least six water sorption/desorption cycles.

\section{Acknowledgements}

This work was supported by the MINECO-Spain through projects PN MAT2012-30994. I.I. and J.A. thank the MINECO for a RyC and FPU predoctoral grant, respectively. ICN2 acknowledges the support of the Spanish MINECO through the Severo Ochoa Centers of Excellence Program, under Grant SEV-2013-0295.

\section{Notes and references}

G. Férey, Chem. Soc. Rev., 2008, 37, 191-214.

C. Janiak, Dalton Trans., 2003, 2781-2804.

S. Kitagawa, R. Kitaura and S. Noro, Angew. Chem. Int. Ed. Engl., 2004, 43, 2334-2375.

4

F. A. Almeida Paz, J. Klinowski, S. M. F. Vilela, J. P. C. Tomé, J. A. S. Cavaleiro and J. Rocha, Chem. Soc. Rev., 2012, 41, 1088-1110. D. Zhao, D. J. Timmons, D. Yuan and H. C. Zhou, Acc. Chem. Res., 2011, 44, 123-133. W. Lu, Z. Wei, Z.-Y. Gu, T.-F. Liu, J. Park, J. Park, J. Tian, M. Zhang, Q. Zhang, T. Gentle Iii, M. Bosch and H.-C. Zhou, Chem. Soc. Rev., 2014, 43, 5561-5593. Shimomura, H. Uehara, M. Nakahama, K. Sugimoto and S. Kitagawa, Nat. Commun., 2011, 2, 168.

J. Park, D. Yuan, K. T. Pham, J.-R. Li, A. Yakovenko and H.-C. Zhou, J. Am. Chem. Soc., 2012, 134, 99-102.

D. H. Busch, Acc. Chem. Res., 1978, 11, 392-400.

T. Hubin, Coord. Chem. Rev., 2003, 241, 27-46.

F. Benetollo, G. Bombieri, L. Calabi, S. Aime and M. Botta, Inorg. Chem., 2003, 42, 148-157.

R. Cibulka, R. Vasold and B. König, Chem. Eur. J., 2004, 10, 6224-6231.

C.-S. Jeung, J. B. Song, Y.-H. Kim and J. Suh, Bioorg. Med. Chem. Lett., 2001, 11, 3061-3064.

E. Tamanini, A. Katewa, L. M. Sedger, M. H. Todd and M. Watkinson, Inorg. Chem., 2009, 48, 319-324.

S. J. Ratnakar, M. Woods, A. J. M. Lubag, Z. Kovacs and A. D. Sherry, J. Am. Chem. Soc., 2008, 130, 6-7.

L. M. De León-Rodríguez, S. Viswanathan and A. D. Sherry, Contrast Media Mol. Imaging, 5, 121-125.

J. M. Taylor, R. K. Mah, I. L. Moudrakovski, C. I. Ratcliffe, R. Vaidhyanathan and G. K. H. Shimizu, J. Am. Chem. Soc., 2010, 132, 14055-14057.

D. A. Knight, J. B. Delehanty, E. R. Goldman, J. Bongard, F. Streich, L. W. Edwards and E. L. Chang, Dalton Trans., 2004, 2006-2011.

G. Ortiz, S. Brandès, Y. Rousselin and R. Guilard, Chem. Eur. J., 2011, 17, 6689-6695.

E. Y. Lee and M. P. Suh, Angew. Chem. Int. Ed. Engl., 2004, 43, 2798-2801.

C. S. Hawes, S. R. Batten and D. R. Turner, CrystEngComm, 2014, 16, 3737-3748.

H.-M. Zhang, H. Wu, Y.-Y. Liu, J. Yang, D.-W. Kang and J.-F. Ma, CrystEngComm, 2015, 17, 1583-1590.

C. S. Hawes, Y. Nolvachai, C. Kulsing, G. P. Knowles, A. L. Chaffee, P. J. Marriott, S. R. Batten and D. R. Turner, Chem. Commun., 2014, 50, 3735-3737.

D. Kong, D. G. Medvedev and A. Clearfield, Inorg. Chem., 2004, 43, 7308-7314.

L. V. Tsymbal, Y. D. Lampeka, V. I. Boyko, V. I. Kalchenko, S. V. Shishkina and O. V. Shishkin, CrystEngComm, 2014, 16, 3707-3711.

W.-Y. Gao, Y. Niu, Y. Chen, L. Wojtas, J. Cai, Y.-S. Chen and S. Ma, CrystEngComm, 2012, 14, 6115-6117.

A. Carné-Sánchez, C. S. Bonnet, I. Imaz, J. Lorenzo, E. Tóth and D. Maspoch, J. Am. Chem. Soc., 2013, 135, 1771117714.

J. Zagal, M. Páez and J. F. Silva, in N4-Macrocyclic Metal Complexes, ed. J. Zagal, F. Bedioui and J.-P. Dodelet, Springer, New York, 2006.

S. Kiatagawa, K. Uemura, Chem. Soc. Rev., 2005, 34, 109119.

W. J. Kabsch, J. Appl. Crystallogr., 1993, 26, 795-800.

G. M. Sheldrick, Acta Crystallogr. Sect. A, 2008, 64, 112122.

S. Brunauer, The Adsorption of Gases and Vapors, Vol 1, Physical Adsorption, Princeton University Press, Princeton, NJ, 1945. 